\title{
PERANCANGAN MATERIAL HANDLING EQUIPMENT PADA PROSES PENGGILINGAN KE OKSIDASI ENZIMATIS BUBUK TEH MENGGUNAKAN METODE PERANCANGAN PRODUK RASIONAL PADA PT PERKEBUNAN NUSANTARA VIII RANCABALI
}

\author{
Imelia Rizki Lestari ${ }^{1}$, Rino Andias Anugraha ${ }^{2}$, Muhammad Iqbal ${ }^{3}$ \\ 1,2,3Program Studi Teknik Industri, Fakultas Rekayasa Industri, Universitas Telkom \\ 1'imeliarizkilestari@gmail.com, ${ }^{2}$ rinoandias@telkomuniversity.ac.id, ${ }^{3}$ muhiqbal@telkomuniversity.ac.id
}

\begin{abstract}
Abstrak-PT Perkebunan Nusantara VIII Rancabali merupakan salah satu perusahaan pengolahan teh hitam ortodoks di Indonesia yang menghasilkan dua belas jenis teh hitam untuk dijual di dalam negeri maupun diekspor ke beberapa negara. Kualitas teh yang dihasilkan oleh perusahaan ini tentunya akan mempengaruhi harga teh yang akan dijual. Dalam proses pengolahan teh hitam ortodoks, proses oksidasi enzimatis merupakan proses yang paling menentukan kualitas bubuk teh yang akan dihasilkan nantinya, sehingga dibutuhkan pengawasan ketat terhadap ketentuan teknis proses tersebut. Proses oksidasi enzimatis pada PT Perkebunan Nusantara VIII Rancabali mulai terjadi saat bubuk teh digiling pada proses penggilingan dan akan berhenti saat bubuk teh dikeringkan pada proses pengeringan. Pada proses penggilingan ke oksidasi enzimatis ditemukan pelaksanaan ketentuan teknis proses oksidasi enzimatis bubuk teh yang tidak sesuai. Dengan menggunakan metode perancangan produk rasional oleh Nigel Cross diharapkan dapat memperbaiki sistem material handling existing menjadi continue dan sesuai dengan ketentuan teknis proses tersebut, sehingga dapat memaksimalkan kualitas bubuk teh yang akan dihasilkan. Perumusan rekomendasi disusun berdasarkan pengolahan data, analisis data, dan diskusi dengan pihak perusahaan yang bertujuan untuk memaksimalkan proses oksidasi enzimatis. Rekomendasi yang diberikan adalah desain perancangan material handling equipment dengan jenis industrial truck khususnya fourwheel hand truck yang disesuaikan dengan ketentuan dalam proses oksidasi enzimatis.
\end{abstract}

Kata kunci: four-wheel hand truck, material handling equipment, Nigel Cross, teh hitam ortodoks, metode perancangan produk rasional.

\section{PENDAHULUAN}

Teh merupakan salah satu komoditas ekspor Indonesia yang cukup penting sebagai penghasil devisa negara sesudah minyak dan gas. Mutu teh Indonesia yang terus mengalami penurunan, penurunan mutu secara timbal balik juga mengakibatkan penurunan harga jual. Dari tujuh jenis produk ekspor teh pada Gambar 1, terdapat dua jenis teh yang paling besar volume ekspornya yaitu Other Black Tea (Fermented)
Dust yang volumenya pada tahun 2009 mencapai 66,075 ton atau sekitar $68.68 \%$ dari total volume ekspor teh dan kemudian Other Black Tea (Fermented) Leaf dengan volume ekspor sebesar 13.677 ton atau sekitar $14.22 \%$ [1].

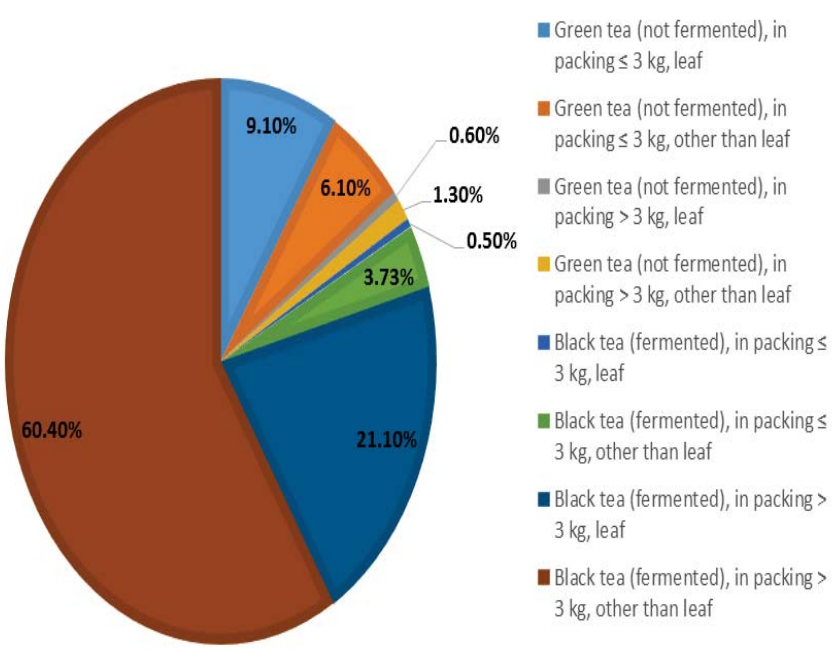

Gambar 1 Perbandingan Volume Teh Ekspor Berdasarkan Jenis Tahun 2013

PT Perkebunan Nusantara VIII Rancabali merupakan salah satu perusahaan besar pengolahan teh hitam orthodoks di Indonesia yang sebagian besar hasilnya diekspor ke luar Indonesia. Pada proses pengolahan teh hitam ortodoks, proses oksidasi enzimatis merupakan proses terpenting dari seluruh proses lainnya karena pada proses ini terjadi reaksi antara enzim dengan udara sehingga membentuk karakteristik teh hitam yaitu rasa, warna pekat dan kenampakan hitam [2]. Untuk memenuhi kualitas yang maksimal, proses oksidasi haruslah dilakukan sesuai dengan ketentuan teknis yang telah ditentukan. Berdasarkan Tabel I dapat dilihat bahwa proses oksidasi enzimatis daun teh yang dialami saat ini melebihi waktu proses yang seharusnya. 
Penumpukan yang terjadi pada mesin pegeringan disebabkan oleh spesifikasi material handling equipment yang digunakan menyebabkan operator harus menuangkan seluruh bubuk teh pada tray ke mesin pengeringan secara menumpuk. Untuk mengatasi masalah tersebut, dibutuhkan sistem material handling yang continue agar bubuk teh masuk ke dalam mesin pengeringan tanpa adanya waktu fermentasi yang berlebihan, sehingga dilakukan perbaikkan terhadap material handling equipment pada proses oksidasi enzimatis [2].

TABEL I

WAKTU PROSES OKSIDASI ENZIMATIS

\begin{tabular}{|c|c|}
\hline No. & $\begin{array}{c}\text { Waktu Proses } \\
\text { (menit) }\end{array}$ \\
\hline 1 & 124.13 \\
\hline 2 & 126.17 \\
\hline 3 & 125.57 \\
\hline 4 & 126.00 \\
\hline 5 & 126.23 \\
\hline 6 & 126.07 \\
\hline 7 & 125.28 \\
\hline 8 & 126.17 \\
\hline 9 & 126.12 \\
\hline 10 & 124.93 \\
\hline 11 & 125.30 \\
\hline 12 & 126.28 \\
\hline 13 & 125.67 \\
\hline 14 & 124.83 \\
\hline 15 & 124.03 \\
\hline
\end{tabular}

\begin{tabular}{|c|c|}
\hline No. & $\begin{array}{c}\text { Waktu Proses } \\
\text { (menit) }\end{array}$ \\
\hline 16 & 124.75 \\
\hline 17 & 125.90 \\
\hline 18 & 125.95 \\
\hline 19 & 125.75 \\
\hline 20 & 125.95 \\
\hline 21 & 126.05 \\
\hline 22 & 125.70 \\
\hline 23 & 124.55 \\
\hline 24 & 124.72 \\
\hline 25 & 125.52 \\
\hline 26 & 124.22 \\
\hline 27 & 124.65 \\
\hline 28 & 124.55 \\
\hline 29 & 125.93 \\
\hline 30 & 125.60 \\
\hline
\end{tabular}

Selain waktu proses oksidasi enzimatis yang berlebihan, ada beberapa penyimpangan yang terjadi terhadap ketentuan teknis proses oksidasi enzimatis yang terjadi pada ruang penggilingan dan oksidasi enzimatis, seperti yang dijelaskan berikut.

1. Dalam sekali pemindahan bahan terdapat tujuh nampan dalam satu material handling equipment, sedangkan dalam satu waktu yang dihasilkan oleh mesin ayakan di ruang penggilingan hanya menghasilkan lima nampan. Dengan demikian akan menyebabkan bubuk yang diangkut dalam satu material handling equipment tidak seragam waktu proses oksidasi enzimatisnya. Peralatan penanganan material yang ada tidak seragam dan akan menyebabkan atas atau di bawah fermentasi dalam proses oksidasi enzimatis.

2. Ketinggian tumpukkan sebaran bubuk teh pada nampan yang melebihi ketentuan teknis yang seharusnya yaitu \pm $12 \mathrm{~cm}$ karena tidak adanya pengukuran ulang atau indikator ketinggian bubuk.

3. Nampan yang digunakan memiliki ketinggian $4 \mathrm{~cm}$, sedangkan tinggi tumpukan optimal dalam proses oksidasi yang $10 \mathrm{~cm}$, sehingga menyebabkan tumpukan bubuk teh pada nampan tidak merata dan akan menyebabkan proses oksidasi enzimatis tidak merata pada seluruh bubuk teh.

Untuk mengatasi masalah tersebut, dibutuhkan sistem penanganan material yang continue dan mendukung ketentuan teknis proses oksidasi enzimatis. Penelitian ini difokuskan pada perancangan material handling equipment pada proses penggilingan ke oksidasi enzimatis untuk memperbaiki kondisi kerja pada proses oksidasi enzimatis yang terjadi. Diharapkan dengan perbaikan material handling equipment mampu meningkatkan dan menjaga konsistensi kualitas teh yang dihasilkan dan meningkatkan harga jual teh untuk ekspor.

\section{METODE PENELITIAN}

Pada penelitian ini, metode yang digunakan adalah metode perancangan produk rasional oleh Nigel Cross. Metode perancangan produk rasional oleh Nigel Cross merupakan metode perancangan produk yang menggunakan pendekatan yang lebih sistematis dalam proses perancangan dibandingkan dengan metode kreatif ${ }^{[3]}$. Adapun tahapan yang digunakan dalam penelitian ini berdasarkan metode perancangan rasional oleh Nigel Cross yaitu clarifying objectives, establishing functions, setting requirements, determining characteristics, generating alternatives, dan evaluating alternatives. Dengan tahapan penelitian menggunakan metode tersebut, terdapat langkah kerja dalam perancangan material handling equipment usulan seperti yang ditampilkan pada Gambar 2. Proses oksidasi enzimatis berlangsung saat teh mulai digiling sampai bubuk akan dikeringkan, sehingga saat proses pemindahan bubuk teh dari proses penggilingan ke oksidasi enzimatis masih terjadi proses oksidasi. Oleh karena itu, penelitian ini berfokus pada perancangan material handling equipment yang dapat membantu proses pemindahan material dari ruang oksidasi ke oksidasi enzimatis.

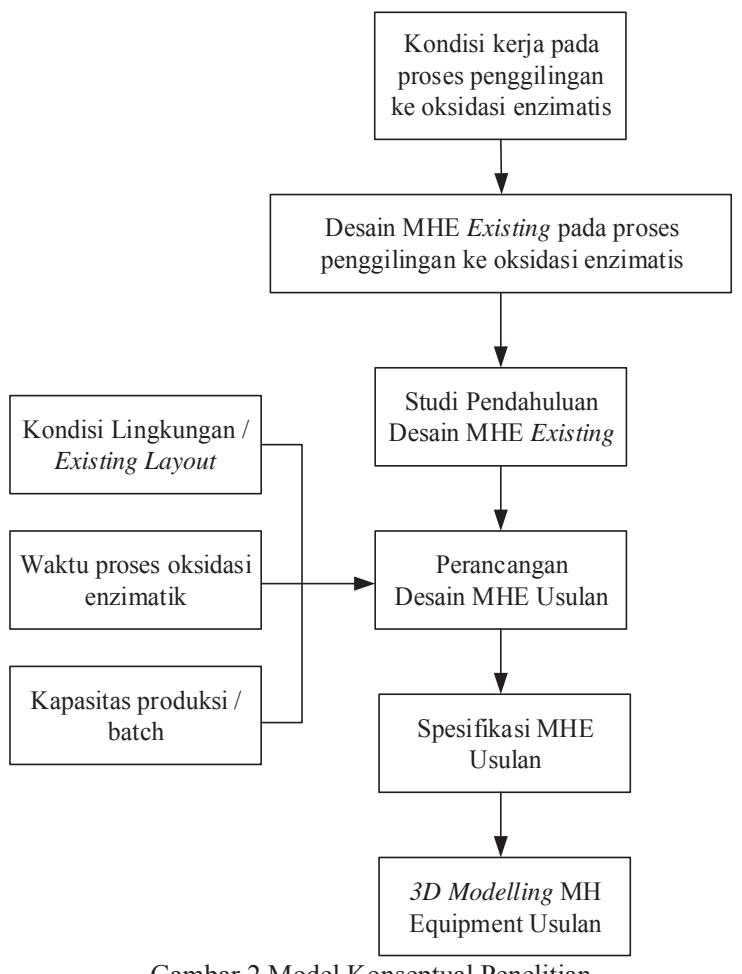

Gambar 2 Model Konseptual Penelitian 
Penelitian ini membutuhkan desain material handling equipment dengan mengamati variabel kebutuhan untuk kesuksesan hasil desain. Variabel kebutuhan ini merupakan tujuan dan batasan dari perancangan material handling equipment yang didapatkan dari hasil identifikasi dan pengumpulan data dengan observasi langsung dan wawancara untuk menentukan atribut baru yang akan menjadi masukan dalam proses perancangan. Wawancara dilakukan terhadap kepala pabrik PT Perkebunan Nusantara VIII Rancabali yang memahami dan mengontrol seluruh proses pengolahan teh hitam ortodoks. Input data yang dibutuhkan dalam proses perancangan penelitian ini adalah kondisi lingkungan/tata letak existing yang ditunjukkan pada Gambar 3, waktu proses oksidasi enzimatis pada Tabel II, dan kapasitas produksi per batch sebesar $120 \mathrm{~kg}$. Input data tersebut kemudian digunakan sebagai variabel kebutuhan untuk mendukung proses perancangan material handling equipment. Input data tersebut kemudian diproses dan disesuaikan dengan tujuan desain dan batasan perancangan untuk menghasilkan spesifikasi material handling equipment. Spesifikasi tersebut kemudian digunakan untuk merancang 3D Modelling konsep material handling equipment yang telah dipilih.

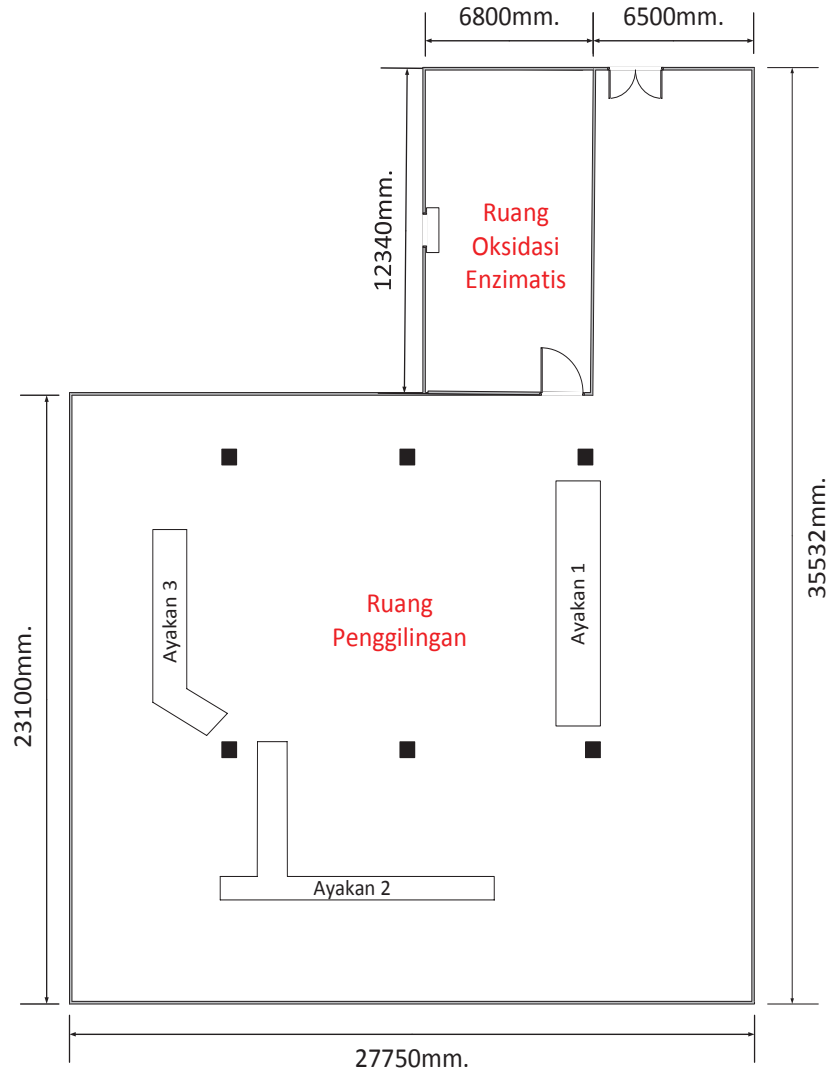

Gambar 3 Tata Letak Existing Ruang Penggilingan dan Oksidasi Enzimatis

TABEL II

\begin{tabular}{|c|c|}
\hline \multicolumn{2}{|c|}{ WAKTU PROSES OKSIDASI ENZIMATIS } \\
\hline & $\begin{array}{c}\text { Waktu proses oksidasi } \\
\text { enzimatis }\end{array}$ \\
\hline Bubuk I: & 120 menit \\
\hline Bubuk II: & $120-130$ menit \\
\hline Badag: & $160-180$ menit \\
\hline
\end{tabular}

\section{HASIL DAN PEMBAHASAN}

\section{A. Clarifying Objectives}

Clarifying Objectives merupakan tahap awal yang dilakukan dengan cara menetapkan tujuan dari perancangan. Pada tahap ini, alat bantu yang digunakan adalah Objectives Tree yang membantu dalam mengidentifikasi tujuan dan subtujuan dari perancangan beserta hubungan antara keduanya. Daftar tujuan diperoleh dari hasil pengamatan peniliti, pertanyaan yang diajukan ke client dan ketentuan teknis proses oksidasi yang sudah divalidasi ke client (customer) ${ }^{[3]}$. Berikut daftar tujuan perancangan initial material handling equipment usulan proses penggilingan ke oksidasi disajikan pada Gambar 4.

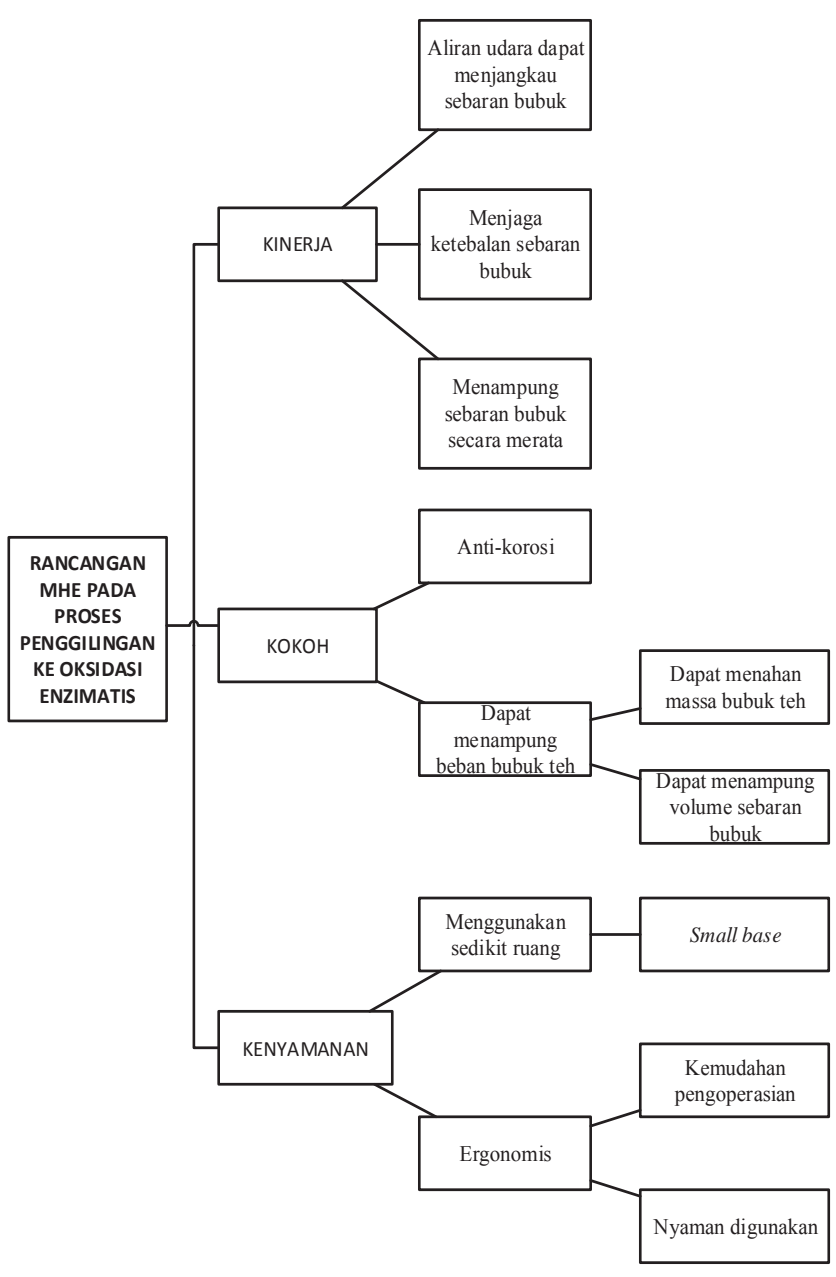

Gambar 4 Objective Tree Perancangan Material Handling Equipment Usulan

Dari tujuan perancangan material handling equipment usulan dan identifikasi material handling equation pada TABEL III, jenis material handling equipment yang memiliki karakteristik yang paling mendekati dengan tujuan perancangan dan karakteristik material handling system pada proses penggilingan ke oksidasi enzimatis yaitu jenis Industrial Truck. 
TABEL III

MATERIAL HANDLING EQUATION

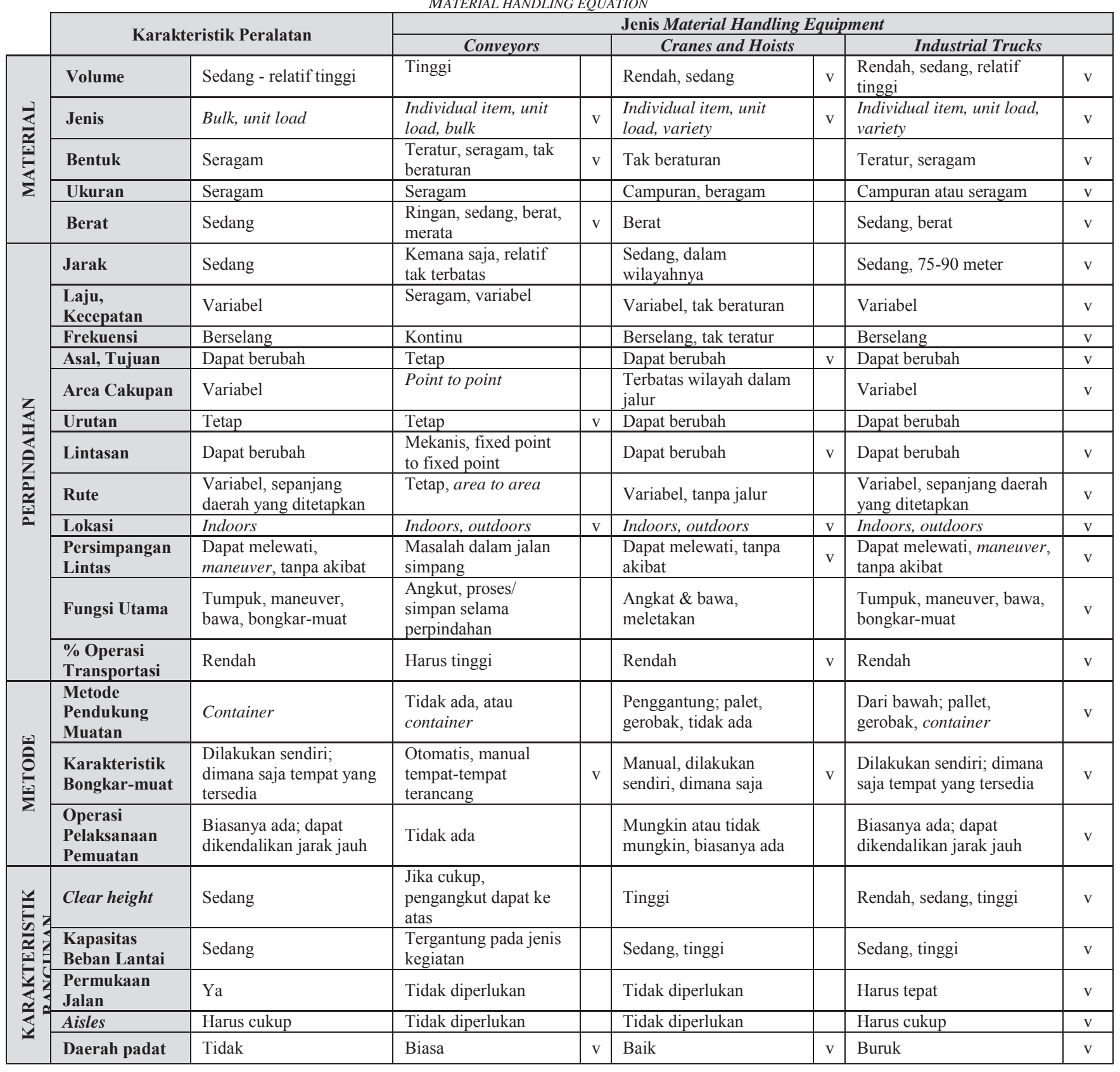

\section{B. Establishing Function}

Tahapan kedua pada proses perancangan material handling equipment usulan adalah establishing function yang menetapkan fungsi-fungsi yang dilakukan dan batas-batas sistem rancangan. Pada tahapan ini alat bantu yang digunakan yaitu Analysis Function yang menggambarkan sistem inputoutput dari proses yang akan dialami di rancangan material handling equipment usulan. Berikut black box model dari rancangan material handling equipment usulan pada Gambar 5. Subfungsi-subfungsi tersebut kemudian digambarkan melalui block diagram (transparent box model) yang menunjukkan interaksi antarsubfungsi yang dipaparkan pada Gambar 6.

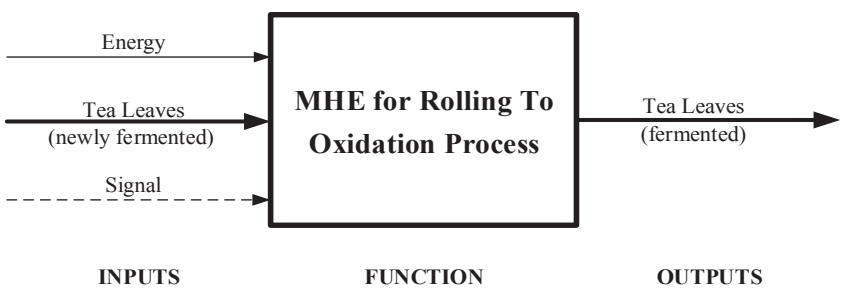

Gambar 5 Diagram Black Box Material Handling Equipment Usulan 


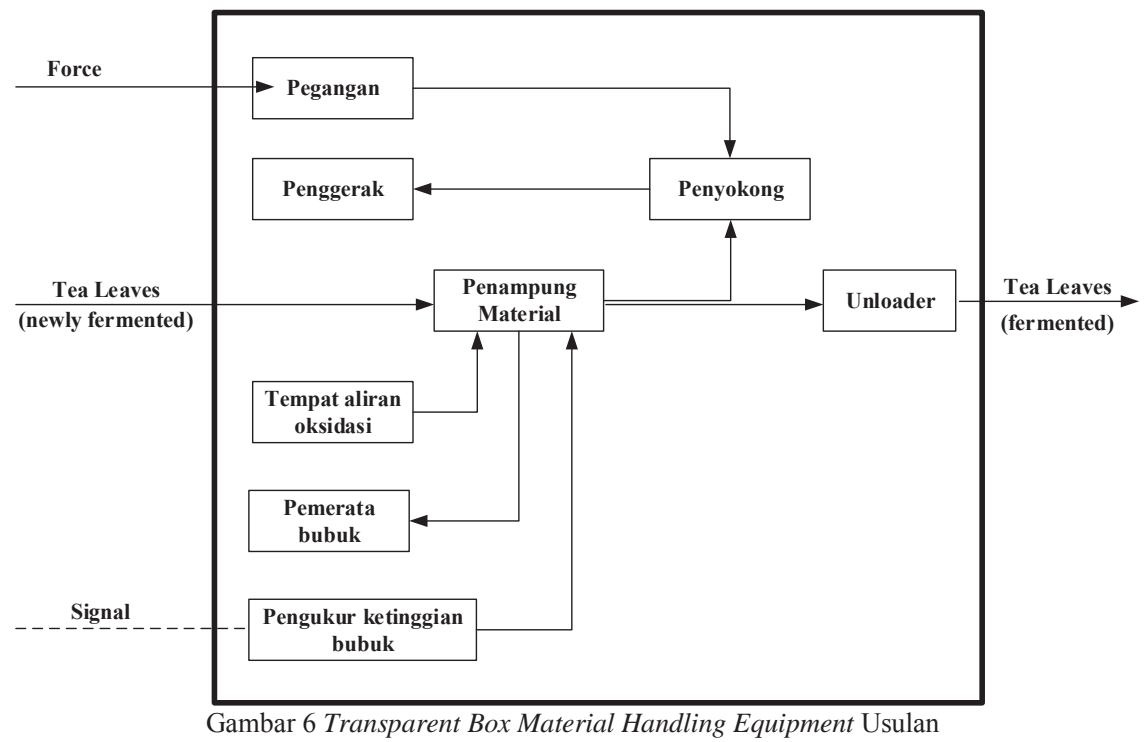

\section{Setting Requirements}

Setelah fungsi dari perancangan material handling equipment usulan ditetapkan, maka yang dilakukan selanjutnya dalam proses perancangan ini adalah menetapkan kebutuhan yang bertujuan untuk membuat spesifikasi perancangan yang akurat bagi designer [3]. Penetapan kebutuhan dilakukan dengan bantuan Performance Specification Model yang disajikan pada Tabel IV.

TABEL IV

SPESIFIKASI PERFORMANSI MATERIAL HANDLING EQUIPMENT USULAN

\begin{tabular}{|c|l|c|c|}
\hline \multicolumn{2}{|c|}{ Tujuan Perancangan } & Parameter & Batasan \\
\hline 1 & $\begin{array}{l}\text { Aliran udara dapat } \\
\text { menjangkau sebaran bubuk }\end{array}$ & $\begin{array}{c}\text { Temperatur } \\
\text { sebaran bubuk }\end{array}$ & $24^{\circ}-28^{\circ} \mathrm{C}$ \\
\hline 2 & $\begin{array}{l}\text { Menjaga ketebalan sebaran } \\
\text { bubuk }\end{array}$ & $\begin{array}{c}\text { Ketebalan sebaran } \\
\text { bubuk }\end{array}$ & $10 \mathrm{~cm}$ \\
\hline 3 & $\begin{array}{l}\text { Menampung sebaran bubuk } \\
\text { secara merata }\end{array}$ & $\begin{array}{c}\text { Kerataan sebaran } \\
\text { bubuk }\end{array}$ & - \\
\hline 4 & Anti-korosi & Anti-korosi & - \\
\hline 5 & $\begin{array}{l}\text { Dapat menahan massa bubuk } \\
\text { teh }\end{array}$ & Kapasitas / MHE & $>12 \mathrm{~kg}$ \\
\hline 6 & $\begin{array}{l}\text { Dapat menampung volume } \\
\text { sebaran bubuk }\end{array}$ & Kapasitas /tray & $80 \mathrm{x} 103 \mathrm{~cm}$ \\
\hline 7 & Small base & Dimensi dasar \\
\hline 8 & Kemudahan pengoperasian & $\begin{array}{c}\text { Jumlah langkah } \\
\text { kerja }\end{array}$ & $<15 \mathrm{steps}$ \\
\hline 9 & Kenyamanan penggunaan & $\begin{array}{c}\text { Kenyamanan } \\
\text { penggunaan }\end{array}$ & - \\
\hline
\end{tabular}

Spesifikasi kinerja yang telah ditetapkan kemudian dapat digunakan sebagai ukuran dalam tahap keenam, yaitu Evaluating Alternatives untuk melihat apakah solusi yang telah dirancang sesuai dengan kriteria yang ditentukan.

\section{Determining Characteristics}

Hubungan antara karakteristik dan atribut produk sangat erat, perancang membuat keputusan tentang sifat fisik produk yang ditentukan dari karakteristik teknis produk tersebut, karakteristik tersebut kemudian ditentukan dari atribut produk yang dapat memenuhi kebutuhan customer. Oleh karena itu, dibutuhkan interpretasi atau pendefinisian dari atribut produk ke karakteristik teknik produk dengan menggunakan Quality Function Deployment (QFD) untuk membantu designer dalam merancang material handling equipment usulan agar memiliki batasan yang ingin dicapai lebih terukur. Penentuan karakteristik perancangan material handling equipment usulan ini dilakukan dengan menggunakan Quality Function Deployment (QFD) dapat dilihat pada Gambar 7.

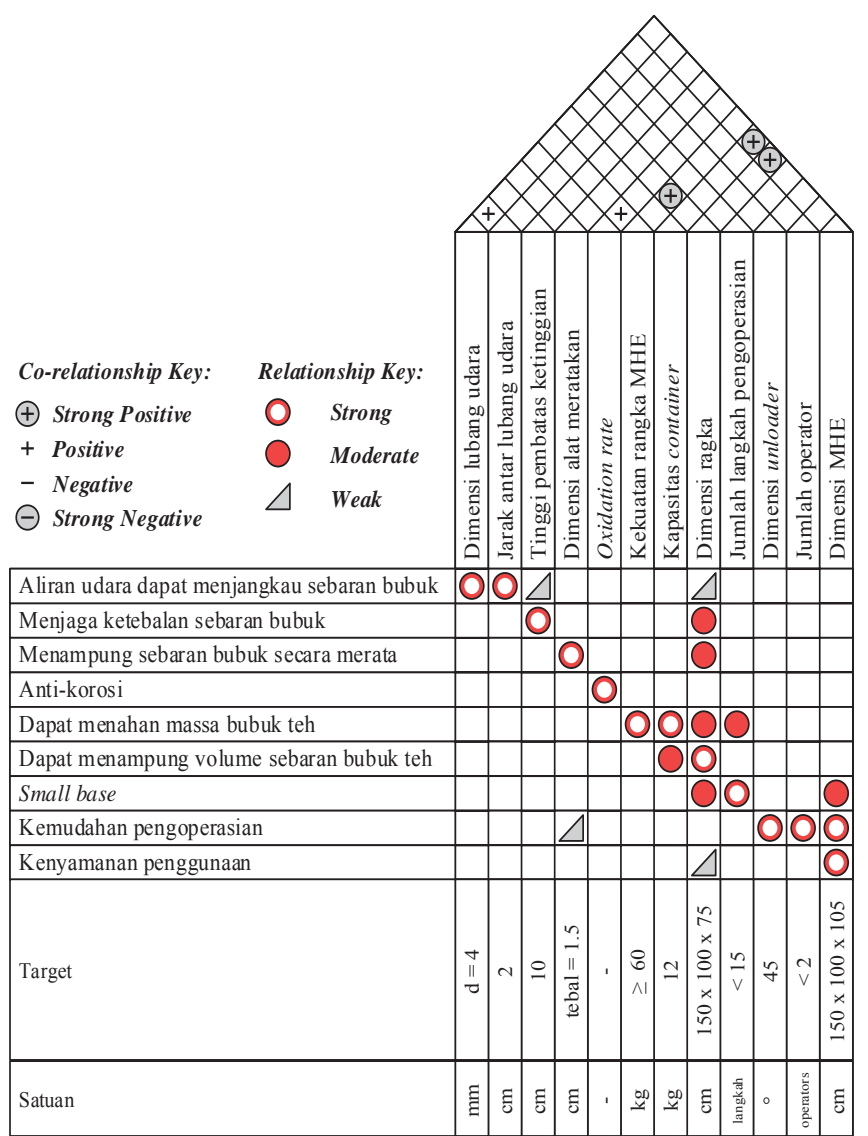


Gambar 7 Quality Function Deployment

Material Handling Equipment Usulan

E. Generating Alternatives

Tahap Generating Alternatives merupakan proses logis dari pemecahan masalah yang menghasilkan beberapa alternatif atau solusi konsep yang belum ada. Alat bantu yang digunakan pada tahapan ini yaitu Morphological Chart. Dengan metode ini semua subsolusi dari setiap fungsi akan dikombinasikan untuk membentuk alternatif atau solusi konsep. Morphological chart akan kehilangan kegunaannya ketika jumlah kolom solusi melebihi tiga atau empat [4], sehingga subsolusi yang memungkinkan dari setiap fungsi dari material handling equipment usulan adalah seperti yang disajikan pada Tabel V.

TABEL V

SUBSOLUSI FUNGSI MATERIAL HANDLING EQUIPMENT USULAN

\begin{tabular}{|c|l|c|c|c|}
\hline \multicolumn{2}{|c|}{ Fungsi } & \multicolumn{3}{c|}{ Sub-solusi } \\
\hline 1 & Container & Rectangular & Circle & Half slot \\
\hline 2 & Frame & 1 Layer & $>1$ Layer & $\begin{array}{c}\text { Lifting } \\
\text { mechanism }\end{array}$ \\
\hline 3 & Unloader & Shovel & Sloping sides & Hole \\
\hline 4 & Driver & Castor & Pneumatic wheel & - \\
\hline 5 & Holder & Side by side & Front side & One point \\
\hline 6 & Hole & Circle & Square & Hexagon \\
\hline 7 & Flattening & Flat & Curve & Hand \\
\hline 8 & Measuring & Ruler & Tape measure & Indicator \\
\hline 9 & Prevent & $\begin{array}{c}\text { Material tray: } \\
\text { Aluminium }\end{array}$ & $\begin{array}{c}\text { Material tray: } \\
\text { Stainless Steel }\end{array}$ \\
\hline
\end{tabular}

Secara teoretikal jumlah konsep yang dihasilkan dari kombinasi subsolusi tersebut adalah $3 \times 3 \times 3 \times 2 \times 3 \times 3 \times 3 \times 3 \times 3=$ 13.122 kombinasi. Dengan jumlah kombinasi yang terlalu besar, perlu dilakukan pereduksian terhadap kombinasi yang ada agar tim perancang dapat fokus dalam mengembangkan konsep. Terdapat dua cara dalam melakukan reduksi kombinasi konsep, pertama, sebuah subsolusi yang tidak layak pada sebuah fungsi dapat dielimanasi sebelum dikombinasikan dengan subsolusi lainnya. Subsolusi yang tidak layak itu adalah subsolusi yang independen dan mempunyai performansi yang paling buruk di antara subsolusi lainnya. Cara kedua yaitu dengan mengeliminasi seluruh kombinasi yang memilki pasangan kombinasi yang tidak cocok/mungkin [3][4]. Setelah dilakukan pereduksian pertama terhadap subsolusi circle, half slot, shovel, pneumatic wheel, one point, square, hexagon, curve, hand, rulee, tape measure, dan aluminium, diperoleh dua belas kombinasi konsep yang disajikan pada Tabel VI. Dari dua belas kombinasi konsep tersebut terdapat kombinasi subsolusi yang tidak memungkinkan yaitu kombinasi subsolusi $>1$ layer dengan hole, sehingga semua konsep yang memiliki kombinasi subsolusi tersebut dieliminasi dan menghasilkan sepuluh konsep yang layak yaitu konsep A, B, C, D, E, F, G, H, I, dan $\mathrm{J}$.

\section{F. Evaluating Alternatives}

Evaluating alternatives merupakan tahap pemilihan alternatif konsep yang terbaik diantara alternatif konsep lainnya yang terbentuk pada tahap generating alternatives. Evaluasi alternatif hanya dapat dilakukan dengan mempertimbangkan tujuan bahwa desain yang seharusnya dicapai dengan menggunakan Weighted Objectives. Tujuan dari metode ini adalah untuk membandingkan nilai utilitas dari desain alternatif sehubungan dengan tujuan desain, atas dasar kinerja terhadap bobot tujuan yang berbeda-beda ${ }^{[3]}$. Pada tahap ini, evaluasi konsep dilakukan dengan menggunakan dua cara yaitu screening concept dan scoring concept untuk menilai dan mengevaluasi kemampuan setiap konsep terhadap tujuan perancangan. Berdasarkan hasil evaluasi terhadap konsep A, B, C, D, E, F, G, H, I, dan J pada Tabel VII dan Tabel VIII, konsep yang terbaik berdasarkan kriteria penilaian yang terpilih yaitu Konsep $\mathrm{H}$.

Dari hasil proses metode perancangan produk rasional untuk material handling equipment usulan pada proses penggilingan ke oksidasi enzimatis dengan spesifikasi akhir pada Tabel IX dan dengan perbandingan antara material handling equipment usulan dan existing pada Tabel X. Desain material handling equipment usulan memiliki kelebihan dan kekurangan dari material handling equipment existing yang digunakan. Namun, material handling equipment usulan ini dirancang dan pemilahan konsep yang berdasarkan tujuan peracangan yang telah ditentukan pada tahap pertama perancangan.

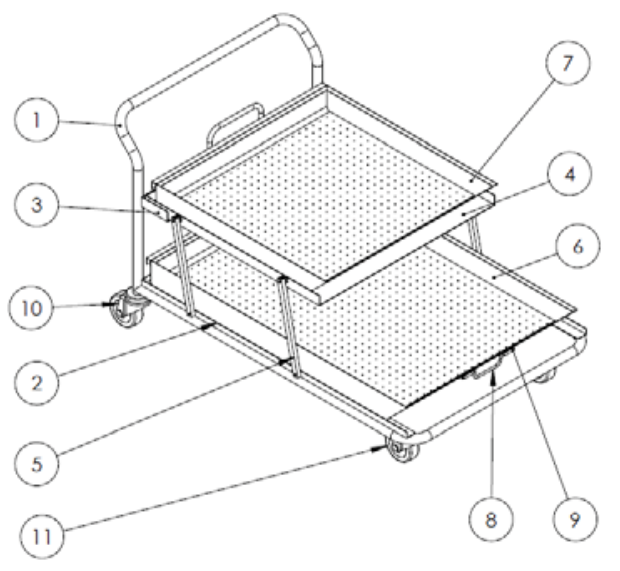

Gambar 8 Konsep H

\begin{tabular}{|c|l|c|}
\hline ITEM NO. & \multicolumn{1}{|c|}{ PART NUMBER } & QTY. \\
\hline 1 & Frame & 1 \\
\hline 2 & Bottom Support & 1 \\
\hline 3 & Top Support & 1 \\
\hline 4 & Lifting Support & 1 \\
\hline 5 & Link Support & 4 \\
\hline 6 & Tray 1 & 1 \\
\hline 7 & Tray 2 & 1 \\
\hline 8 & Handle for Tray 1 & 2 \\
\hline 9 & Assembly for handle & 2 \\
\hline 10 & Break castor & 2 \\
\hline 11 & Free Castor & H \\
\hline
\end{tabular}

Gambar 9 Bill of Material Konsep $\mathrm{H}$ 
TABEL VI

MORPHOLOGICAL CHART MATERIAL HANDLING EQUIPMENT USULAN

\begin{tabular}{|c|c|c|c|c|c|c|c|c|c|}
\hline \multirow{2}{*}{ Konsep } & \multicolumn{9}{|c|}{ Subsolusi } \\
\cline { 2 - 11 } & Container & Frame & Unloader & Driver & Holder & Hole & Flattening & Measuring & Prevent \\
\hline $\mathrm{A}$ & Rectangle & 1 Layer & Sloping Sides & Castor & Side by side & Circle & Flat & Indicator & Stainless Stell \\
\hline $\mathrm{B}$ & Rectangle & 1 Layer & Sloping Sides & Castor & Front side & Circle & Flat & Indicator & Stainless Stell \\
\hline $\mathrm{C}$ & Rectangle & 1 Layer & Hole & Castor & Side by side & Circle & Flat & Indicator & Stainless Stell \\
\hline $\mathrm{D}$ & Rectangle & 1 Layer & Hole & Castor & Front side & Circle & Flat & Indicator & Stainless Stell \\
\hline $\mathrm{E}$ & Rectangle & $>1$ Layer & Sloping Sides & Castor & Side by side & Circle & Flat & Indicator & Stainless Stell \\
\hline $\mathrm{F}$ & Rectangle & $>1$ Layer & Sloping Sides & Castor & Front side & Circle & Flat & Indicator & Stainless Stell \\
\hline Elimntd & Rectangle & $>1$ Layer & Hole & Castor & Side by side & Circle & Flat & Indicator & Stainless Stell \\
\hline Elimntd & Rectangle & $>1$ Layer & Hole & Castor & Front side & Circle & Flat & Indicator & Stainless Stell \\
\hline $\mathrm{G}$ & Rectangle & Lifting Mech. & Sloping Sides & Castor & Side by side & Circle & Flat & Indicator & Stainless Stell \\
\hline $\mathrm{H}$ & Rectangle & Lifting Mech. & Sloping Sides & Castor & Front side & Circle & Flat & Indicator & Stainless Stell \\
\hline $\mathrm{I}$ & Rectangle & Lifting Mech. & Hole & Castor & Side by side & Circle & Flat & Indicator & Stainless Stell \\
\hline $\mathrm{J}$ & Rectangle & Lifting Mech. & Hole & Castor & Front side & Circle & Flat & Indicator & Stainless Stell \\
\hline
\end{tabular}

TABEL VII

SCREENING CONCEPT

\begin{tabular}{|c|c|c|c|c|c|c|c|c|c|c|c|}
\hline \multirow{2}{*}{ Kriteria Pemilihan } & \multicolumn{11}{|c|}{ Konsep } \\
\hline & $\mathbf{A}$ & B & $\mathbf{C}$ & D & $\mathbf{E}$ & $\mathbf{F}$ & G & $\mathbf{H}$ & I & $\mathbf{J}$ & Ref. \\
\hline Aliran udara dapat menjangkau sebaran bubuk & 0 & 0 & 0 & 0 & 0 & 0 & 0 & 0 & 0 & 0 & 0 \\
\hline Menjaga ketebalan sebaran bubuk & + & + & + & + & + & + & + & + & + & + & 0 \\
\hline Menampung sebaran bubuk secara merata & + & + & + & + & + & + & + & + & + & + & 0 \\
\hline Anti-korosi & - & - & - & - & - & - & - & - & - & - & 0 \\
\hline Dapat menahan massa bubuk teh & + & + & + & + & + & + & + & + & + & + & 0 \\
\hline Dapat menampung volume sebaran bubuk & + & + & + & + & 0 & 0 & + & + & + & + & 0 \\
\hline Small base & - & - & - & - & 0 & 0 & - & - & - & - & 0 \\
\hline Kemudahan pengoperasian & - & - & - & - & 0 & 0 & + & + & - & - & 0 \\
\hline Kenyamanan penggunaan & - & + & - & + & - & 0 & - & + & - & + & 0 \\
\hline Sum +'s & 4 & 5 & 4 & 5 & 3 & 3 & 5 & 6 & 4 & 5 & $\mathbf{0}$ \\
\hline Su m 0's & 1 & 1 & 1 & 1 & 4 & 5 & 1 & 1 & 1 & 1 & 9 \\
\hline Sum -'s & 4 & 3 & 4 & 3 & 2 & 1 & 3 & 2 & 4 & 3 & $\mathbf{0}$ \\
\hline Net Score & $\mathbf{0}$ & 2 & 0 & 2 & 1 & 2 & 2 & 4 & 0 & 2 & 0 \\
\hline Rank & 8 & 2 & 8 & 2 & 7 & 2 & 2 & 1 & 8 & 2 & 8 \\
\hline Continue? & No & Yes & No & Yes & No & Yes & No & Yes & No & No & No \\
\hline
\end{tabular}

TABEL VIII

SCORING CONCEPT

\begin{tabular}{|c|c|c|c|c|c|c|c|c|c|}
\hline \multirow{3}{*}{ Kriteria Pemilihan } & \multirow{3}{*}{$\begin{array}{c}\text { Bobot } \\
(\%)\end{array}$} & \multicolumn{8}{|c|}{ Konsep } \\
\hline & & \multicolumn{2}{|r|}{ D } & \multicolumn{2}{|c|}{ D } & \multicolumn{2}{|r|}{$\mathbf{F}$} & \multicolumn{2}{|c|}{$\mathbf{H}$} \\
\hline & & Rating & $\begin{array}{c}\text { Weighted } \\
\text { Score }\end{array}$ & Rating & $\begin{array}{c}\text { Weighted } \\
\text { Score }\end{array}$ & Rating & $\begin{array}{c}\text { Weighted } \\
\text { Score }\end{array}$ & Rating & $\begin{array}{c}\text { Weighted } \\
\text { Score }\end{array}$ \\
\hline $\begin{array}{l}\text { Aliran udara dapat menjangkau sebaran } \\
\text { bubuk }\end{array}$ & 16.12 & 3 & 0.45 & 3 & 0.45 & 3 & 0.45 & 3 & 0.45 \\
\hline Menjaga ketebalan sebaran bubuk & 16.12 & 3 & 0.45 & 3 & 0.45 & 3 & 0.45 & 3 & 0.45 \\
\hline Menampung sebaran bubuk secara merata & 16.12 & 3 & 0.45 & 3 & 0.45 & 3 & 0.45 & 3 & 0.45 \\
\hline Anti-korosi & 9.67 & 3 & 0.3 & 3 & 0.3 & 3 & 0.3 & 3 & 0.3 \\
\hline Dapat menahan massa bubuk teh & 9.67 & 2 & 0.2 & 2 & 0.2 & 3 & 0.3 & 3 & 0.3 \\
\hline Dapat menampung volume sebaran bubuk & 9.67 & 4 & 0.4 & 4 & 0.4 & 1 & 0.1 & 3 & 0.3 \\
\hline Small base & 3.22 & 1 & 0.5 & 1 & 0.5 & 4 & 2 & 3 & 1.5 \\
\hline Kemudahan pengoperasian & 12.9 & 3 & 0.375 & 2 & 0.25 & 1 & 0.125 & 5 & 0.625 \\
\hline Kenyamanan penggunaan & 6.06 & 1 & 0.075 & 1 & 0.075 & 3 & 0.225 & 4 & 0.3 \\
\hline \multicolumn{2}{|l|}{ Total Score } & \multicolumn{2}{|r|}{3.2} & \multicolumn{2}{|c|}{3.075} & \multicolumn{2}{|c|}{4.4} & \multicolumn{2}{|c|}{4.675} \\
\hline \multicolumn{2}{|l|}{ Rank } & \multicolumn{2}{|r|}{4} & \multicolumn{2}{|c|}{5} & \multicolumn{2}{|c|}{3} & \multicolumn{2}{|c|}{1} \\
\hline \multicolumn{2}{|l|}{ Continue? } & \multicolumn{2}{|c|}{ No } & \multicolumn{2}{|c|}{ No } & \multicolumn{2}{|c|}{ No } & \multicolumn{2}{|c|}{ Develop } \\
\hline
\end{tabular}

Perancangan Material Handling Equipment pada Proses Penggilingan Ke Oksidasi Enzimatis Bubuk Teh Menggunakan Metode Perancangan Produk Rasional pada PT Perkebunan Nusantara VIII Rancabali 
TABEL IX

SPESIFIKASI AKHIR MATERIAL HANDLING EQUIPMENT USULAN

\begin{tabular}{|c|c|c|}
\hline Karakteristik Teknis & Nilai & Satuan \\
\hline Dimensi lubang udara & $\mathrm{d}=4$ & $\mathrm{~mm}$ \\
\hline Jarak antar lubang udara & $2 \mathrm{~cm}$ & $\mathrm{~cm}$ \\
\hline Batas ketinggian bubuk teh & $10 \mathrm{~cm}$ & $\mathrm{~cm}$ \\
\hline Dimensi alat bantu meratakan & $40 \times 15 \times 1.5$ & $\mathrm{~cm}$ \\
\hline Oxidation rate & - & - \\
\hline Kapasitas MHE & 75 & $\mathrm{~kg}$ \\
\hline Kapasitas Tray 1 & 45 & $\mathrm{~kg}$ \\
\hline Kapasitas Tray 2 & 30 & $\mathrm{~kg}$ \\
\hline Dimensi rangka & $160 \times 105.2 \times 85$ & $\mathrm{~cm}$ \\
\hline Jumlah langkah pengoperasian & 10 & $\mathrm{steps}$ \\
\hline Dimensi unloader & 45 & derajat \\
\hline Jumlah operator & 1 & operator \\
\hline Dimensi MHE & $160 \times 105.2 \times 105$ & $\mathrm{~cm}$ \\
\hline Dimensi Nampan 1 & $100 \times 150 \times 12.5$ & $\mathrm{~cm}$ \\
\hline Dimensi Nampan 2 & $100 \times 100 \times 12.5$ & $\mathrm{~cm}$ \\
\hline Ketebalan nampan & 2 & $\mathrm{~mm}$ \\
\hline Material nampan & Stainless steel & - \\
\hline
\end{tabular}

TABEL X

PERBANDINGAN SPESIFIKASI MATERIAL HANDLING EQUIPMENT EXISTING DAN USULAN

\begin{tabular}{|c|l|c|c|}
\hline No. & \multicolumn{1}{|c|}{ Spesifikasi } & Existing & Usulan \\
\hline 1 & Temperatur bubuk teh & $24^{\circ}-28^{\circ} \mathrm{C}$ & $24^{\circ}-28^{\circ} \mathrm{C}$ \\
\hline 2 & Ketebalan bubuk teh & $12 \mathrm{~cm}$ & $10 \mathrm{~cm}$ \\
\hline 3 & Kerataan sebaran bubuk & Menggunung & Rata \\
\hline 4 & Anti-korosi & Ya & Ya \\
\hline 5 & Kapasitas /MHE & 7 nampan & 2 nampan \\
\hline 6 & Kapasitas/nampan & $80 \times 103 \mathrm{~kg}$ & 30 and $45 \mathrm{~kg}$ \\
\hline 7 & Dimensi rangka & $\begin{array}{c}160 \times 105.2 \mathrm{~cm} \\
105 \mathrm{~cm}\end{array}$ \\
\hline 8 & Jumlah langkah operasi & 22 step & 9 step \\
\hline 9 & Jumlah operator & 2 operator & 1 operator \\
\hline 10 & Material nampan & Fiber glass & $\begin{array}{c}\text { Stainless } \\
\text { Steel }\end{array}$ \\
\hline
\end{tabular}

\section{KESIMPULAN}

Dari hasil pengolahan data, analisis data, dan usulan yang telah dibuat, maka diperoleh kesimpulan yang mengacu pada tujuan untuk menyelesaikan permasalahan yang diangkat dalam penelitian ini. Jenis material handling equipment yang cocok pada proses penggilingan ke oksidasi enzimatis adalah jenis industrial truck khususnya four-wheel hand truck. Untuk mencapai tujuan perancangan yaitu untuk meningkatkan kemampuan material handling equipment terhadap ketentuan teknis proses oksidasi enzimatis, maka material handling equipment usulan dirancang dengan ukuran 160x105.2x105 $\mathrm{cm}$, memiliki dua layer penyimpanan yang menggunakan lifting mechanism, dengan batas ketinggian bubuk sebesar 10 $\mathrm{cm}$ pada tray, memiliki alat bantu meratakan bubuk teh yang ditampung, lubang udara sebesar $4 \mathrm{~mm}$ dengan jarak antarlubang $2 \mathrm{~cm}$, unloader berupa sisi miring, dan pengoperasiannya yang dapat dilakukan oleh satu operator.

\section{DAFTAR PUSTAKA}

[1] Badan Pusat Statistik Republik Indonesia. 2013. [Online]. Available:

http://www.bps.go.id/hasil_publikasi/flip_2011/5504001 /index 11.php?pub=Statistik\%20Teh\%20Indonesia\%202 010. [Accessed 21 December 2014].

[2] R. Soedradjat. Panduan Pengolahan Teh Hitam Ortodoks Sistem Penggilingan Kontinu. Bandung: Penerbit ITB.

[3] N. Cross. Engineering Design Methods: Strategies for Product Design, Third penyunt. England: John Wiley, 2000.

[4] K. T. Ulrich dan S. D. Eppinger, Product Design and Development, 5th penyunt. New York: McGraw-Hill, 2012. 